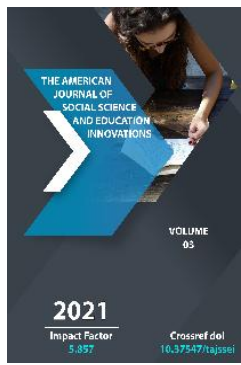

\section{Natural Resource Inventories In A Changing Climate: Problems Of Improving The Mechanism Of Cadastral Activites And Ways To Solve Them}

\author{
Robiya Toshboyeva \\ Tashkent State Law University, Acting Associate Professor Of Ecological Law, Candidate Of \\ Legal Sciences, Uzbekistan
}

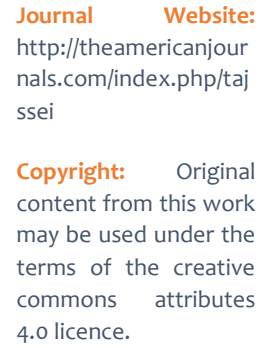

Copyright: Original content from this work may be used under the terms of the creative commons attributes 4.0 licence.

\title{
ABSTRACT
}

The article discloses the legal basis for conducting cadastral activities, as well as the nature of legal disparities in the distribution of powers of the competent bodies dealing with cadastres of natural resources. The author analyzed the legislative base for cadastres of natural resources, national and foreign literature as well as foreign experience in maintaining natural cadastres and developed relevant proposals and recommendations for improving legislation in the field of cadastral activities of natural resources.

\section{KEYWORDS}

public administration, cadastral activites, public private partnerships, cadastral information, legal disproportion, bodes of general competence, specialized body, natural resource inventories, the Unified electronic information center.

\section{INTRODUCTION}

The relevance of the problem. Careful consideration of the available natural resources is an indispensable sign of a prosperous state. At present, no one doubts the need for a market valuation of natural assets. Consumers of this information are almost all participants in economic relations, including enterprises and organizations of various forms of ownership, state institutions and individuals. The lack of reliable information

about the country's natural potential negatively affects the state of economic development and the environment. President of the Republic of Uzbekistan Shavkat Mirziyoyev, speaking at the fifth Summit of the Conference on Interaction and Confidence-building Measures in Asia, held on June 15, 2019 in Dushanbe, noted that 
"escalating environmental threats are a serious challenge to security and sustainable development" . In order to prevent future and solve current environmental problems, it is necessary to constantly improve the existing system of providing real information about the state of natural resources, which is inextricably linked with the achievements of technological progress. In the modern world, every subject of law is guaranteed the right to receive information, in particular, information about the natural resources of the state, which is contained in the state cadastre of natural resources. Competent management of the collection, processing, storage and provision of information about natural resources is one of the key problems of environmental legislation in general, as practice shows that any modern activity is based primarily on statistical data. The solution to this problem will primarily serve the task of rational use of natural resources, set by the President of the Republic of Uzbekistan Shavkat Mirziyoyev in his Address to the Oliy Majlis dated December 28, 2018 , the essence of which is to waste them today and bring them to the younger generation tomorrow, which will constitute the essence of sustainable development. According to statistics, Uzbekistan is among the world leaders in the availability of reserves of silver, tungsten and phosphorites, potassium salt, rare earth metals and other valuable minerals, in particular, in the proven reserves of gold on the fourth, uranium - seventh, molybdenum eighth, in the confirmed reserves of copper on the tenth, natural gas - the fourteenth place in the world; in the area of artificially irrigated land - on the eleventh place in the world; in the production of cadmium - on the third, uranium - on the sixth, gold and natural gas - in eighth place. In addition, Uzbekistan is among the 15 largest countries on the planet for the extraction of molybdenum, feldspar and a number of other types of industrial raw materials. Our task is to maintain this position of Uzbekistan in the international arena, and at the same time, the main mechanism for achieving it is to establish competent management in the field of cadastral information formation.

In this regard, in the context of global climate warming, which is also acutely felt in Uzbekistan, the population's need for reliable information about the state of natural resources is increasing, which in turn leads to the destruction of the environment. We support the opinion of German scientists who believe that it is possible to solve the problem of climate change through the education and training of economic entities with environmental socio-cultural responsibility.

This proposal fully applies to legal entities whose competence includes the formation and provision of information about natural resources. The relevance of this topic, in our opinion, is dictated by the following points:

first, there is a certain legal disparity in the powers of the competent authorities involved in the management of state cadastres of natural resources in the current legislation, which requires immediate elimination; second, today we do not have a single body whose main and only function would be to maintain state cadastres of natural resources; third, the lack of a mechanism for non-state regulation of cadastral activities in relation to natural resources hinders its further improvement. Turning directly to the essence of the topic under study, I would like to note that the state cadastre of natural resources is one of the tools of state control over the state of the environment, the essence of which has recently changed significantly due to the expansion of its goals, objectives and functions. To date, Uzbekistan has formed a comprehensive regulatory and legal framework for public administration in the field of maintaining state cadastres of natural resources, defined the procedure for its formation, and distributed powers among the relevant bodies. 
The main components of its regulatory framework are the Land Code of the Republic of Uzbekistan, the laws of the Republic of Uzbekistan "On State Cadastres" and "On the State Land Cadastre" , the Regulations on the procedure for Creating and Maintaining a Unified System of State Cadastres, the Regulations on the Procedure for Maintaining the State Land Cadastre, the Regulations on the procedure for developing and Maintaining the state water Cadastre [, the Regulations on the procedure for Maintaining state Accounting, Accounting for the Volume of Use and the state Cadastre of Wildlife Objects , Regulations on the procedure for maintaining state records, accounting for the volume of use and the state cadastre of Flora Objects [, Regulations on the Procedure for Maintaining the State Cadastre of Protected Natural Territories of the Republic of Uzbekistan [, Regulations on the Procedure for Maintaining the State Cadastre of Deposits, Mineral Manifestations and Man-made Formations of the Republic of Uzbekistan, Regulations on the procedure for maintaining the state Forest Cadastre in the Republic of Uzbekistan . Despite this, the legislation regulating this area requires further improvement due to the presence of imperfect points in it, which are manifested in the following. According to the current legislation, we have a three-stage system of state bodies that maintain state cadastres of natural resources. These include: 1. bodies of general competence. These are the Cabinet of Ministers of the Republic of Uzbekistan, local state authorities; 2 . bodies of special competence that maintain a unified system of State Cadastres. These include the State Committee of the Republic of Uzbekistan on Land Resources, Geodesy, Cartography and State Cadastre; 3. bodies directly responsible for maintaining state cadastres of natural resources. These include ministries, state committees, and departments.

The law" On State Cadastres " specifies the powers of the Cabinet of Ministers of the
Republic of Uzbekistan, local State authorities and a specialized body in the field of maintaining state cadastres of natural resources. The powers of the Cabinet of Ministers include: implementation of a unified state policy, determination of priority areas for the development of state cadastres, resolution of issues of financing and investment; determination of the procedure for maintaining a Unified system of State Cadastres; establishing the procedure for conducting state registration of rights to cadastral objects, providing cadastral information to users, etc. The competence of local state authorities includes: organization of state registration of rights to cadastral objects; in accordance with the procedure established by law, financing from the local budget of the work on the maintenance of the state land cadastre, the state cadastre of buildings and structures; organize the maintenance of the state cadastre of the relevant territories, etc. The State Committee of the Republic of Uzbekistan for Land Resources, Geodesy, Cartography and State Cadastre (Goskomzemgeodezkadastr) is a specially authorized body in the field of state cadastre management. Its competence includes: coordination of the activities of ministries, state committees, departments and bodies of state power in the field of maintaining state cadastres; implementation of the Unified System of State Cadastres; providing the ministries, state committees and departments with cartographic materials necessary for maintaining the relevant state cadastres in accordance with the established procedure; approving normative acts on maintaining state cadastres in accordance with the established procedure; organizing training and advanced training of specialists, etc. Ministries, state committees, and departments that directly maintain state cadastres of natural resources include: the State Committee of the Republic of Uzbekistan for Land Resources, Geodesy, Cartography, and the State Cadastre, which maintains the State land cadastre; the State 
Committee of the Republic of Uzbekistan for Geology and Mineral Resources, which maintains the state cadastre of deposits, mineral occurrences, and man-made formations; The Center of the Hydrometeorological Service under the Ministry of Emergency Situations of the Republic of Uzbekistan, the State Committee of the Republic of Uzbekistan on Geology and Mineral Resources, the Ministry of Water Management of the Republic of Uzbekistan, which maintain the state water cadastre; the State Committee of the Republic of Uzbekistan on Forestry, which maintains the state forest cadastre;

The State Committee of the Republic of Uzbekistan for Ecology and Environmental Protection, which maintains the state cadastre of flora objects, the state cadastre of fauna objects, the state cadastre of protected natural territories, the state cadastre of places of burial and waste disposal. As can be seen from the analysis of the current legislation, there is a certain legal disparity in the powers of state bodies. We can observe this disparity in the following cases:

a) The state water cadastre, which is an independent cadastre, is maintained by three bodies simultaneously: the Center of the Hydrometeorological Service under the Ministry of Emergency Situations of the Republic of Uzbekistan (natural Water sources), the State Committee of the Republic of Uzbekistan for Geology and Mineral Resources (Underground waters), and the Ministry of Water Management of the Republic of Uzbekistan (use of water resources and land reclamation), this, in turn, leads to fragmentation of existing responsibilities and the lack of a unified approach to the formation of cadastral data.

b) The State Committee of the Republic of Uzbekistan for Ecology and Environmental Protection alone simultaneously maintains four independent state cadastres of natural resources: the state cadastre of flora objects, the state cadastre of fauna objects, the state cadastre of protected natural territories, the state cadastre of places of burial and waste disposal;

c) Cabinet of Ministers Resolution № 599 of July 17, 2019 introduces the concept of "cadastre of agricultural land", which includes information only on agricultural land (while the current legislation establishes the concept of" state land cadastre") and defines the bodies and criteria for information on agricultural land - In accordance with this resolution: the State Land Administration bodies must provide information about the name of the user of the land plot, its economic and legal regimes, location, border, contours, area, categories and types of land, soil fertility; water management bodies should provide information about the degree of water availability of land, methods of water intake for irrigation, the reclamation state of the soil, the level and composition of underground water, the state of collector and drainage networks, programs for capital and current repairs of irrigation networks and structures, pumping stations, and others.;

agricultural authorities should provide information about the types of crops intended for sowing, the state of orchards, vineyards and other plantings, information about the available types of livestock, poultry, as well as bee keeping, fishing, proposals for a more optimal direction for the future of agricultural organizations; Councils of farmers, dehkan farms and owners of household plots should provide information about existing farms. This "fragmentation" of the state land cadastre into categories of land included in the land fund of the Republic of Uzbekistan and its distribution (as in the above case with the state water cadastre) to several bodies is another example of a clear disparity in the powers of state bodies involved in maintaining natural resource inventories. In addition, to 
date, the State Committee of the Republic of Uzbekistan for Land Resources, Geodesy, Cartography and State Cadastre is responsible for maintaining a Unified System of State Cadastres, which covers from the implementation of state management in the field of ecology, environmental protection, rational use and reproduction of natural resources to ensuring close interaction with the public and civil society institutions in matters of ecology and environmental protection, the rights of citizens to a favorable environment, at the same time, the maintenance of the state cadastre is only one of its tasks. At the same time, one of the most painful points of conducting cadastral activities is the issue of its financing. The Law of the Republic of Uzbekistan "On State Cadastres" stipulates that the financing of maintaining state cadastres is carried out at the expense of the State budget of the Republic of Uzbekistan and other sources not prohibited by law. Other sources include investments, both domestic and foreign, and the mixing of capital in the form of publicprivate partnerships, which is understood as a legally formalized cooperation between a public partner and a private partner for a certain period of time, based on the pooling of their resources for the implementation of a public-private partnership project. Moreover, we have a legislative framework ready for this.

Thus, the law of the Republic of Uzbekistan "On Public-Private Partnership" establishes the improvement of the quality of public services and the expansion of access to them as one of the main directions of state policy in the field of public-private partnership. Given that the provision of cadastral information on natural resources is one of the types of services, the issue of developing public-private partnerships in the field of cadastral activities remains open.

For comparison. In the Russian Federation, information about real estate objects, including land plots, for their state cadastral registration is prepared by licensed private specialists (in relation to land plots - land engineers) and companies called "cadastral engineers", within the framework of cadastral activities. At the same time, a cadastral engineer who carries out cadastral activities as an individual entrepreneur must register in accordance with the procedure established by law. For his work as an employee of a legal entity, a cadastral engineer enters into an employment contract with a commercial organization, which in turn enters into contracts for performing cadastral works. To solve these problems, we considered it necessary to analyze the foreign experience of conducting cadastral activities. In particular, in the Federal State of Saxony, the land cadastre is the responsibility of the Ministry of the Interior and the Land Geodetic Administration, which control the activities of 18 state institutions of geodesy and land management, as well as city geodesy institutions, state licensed surveyors. In a number of other German states, the Ministry of Finance, the Ministry of Economic Development, and others decide on land management and land cadastre management. Cadastral work is carried out by land cadastre departments, which usually belong to the Ministry of Internal Affairs or the Ministry of Justice. The survey is paid for by land owners and public organizations. In France, the inventory of natural resources is maintained by the National Cadastre Service and the local zonal tax departments. The tasks of the State Service of Cadastral Documents are the preparation of cadastral surveys and their storage. Zonal tax state departments are engaged in updating the available information, on the basis of which they tax taxpayers. At present, France has an automated cadastre system, which consists of 5 zonal computing centers and 306 local cadastre offices, providing the tax authorities with the latest cadastral information. The main task of the automated system is to collect, store, and process information about land plots and real estate objects. 
In the United States, there is a Cadastre Service that operates in 85 district courts under the district courts of the Department of Justice. The Cadastre Service maintains cadastres for all natural resources, they provide the market price of a natural resource, collect characteristics, if the land is sown, then indicate the average yield.The land registry in the United States is maintained by a special soil protection service in the system of the Department of Agriculture. It consists of a central authority, branches in the states, and about 2,400 district cells for the protection of US soil.

The main task of the cadastre in Spain is to ensure the tax policy for real estate, so it is under the jurisdiction of the Ministry of Economy and Property, which is responsible for collecting taxes. Real estate accounting in Spain is carried out by the State Secretariat for Property, which reports to the General Directorate of Cadastre, established in 1978 to manage all land cadastre work. Cadastral information is compiled by the Spanish cadastre center, which includes the collection, processing, storage and updating of cadastral information. The special content of cadastral works consists in creating cadastral maps by aerial and photogrammetric methods, determining and fixing the boundaries of land plots, coding, searching and justifying methods of valuation of real estate. Private firms are engaged in the preparation of cadastral maps and plans, which gives a good result. For six years, the Spanish government has spent $\$ 1$ billion on the compilation and maintenance of inventories, while in the last three years, the profit from the implementation of the inventory amounted to $\$ 2.5$ billion. Spain currently has 23 million people. Real estate units, of which 20 million are agricultural plots, updated by 70 percent .

In Sweden, cadastres are also multi-purpose. Cadastral information about land plots, the rights of owners to land and real estate is recorded in a special registration book, and the amount of taxes is determined. The Swedish Land Cadastre is part of the land services and consists of three levels. A special feature of the Swedish land cadastre is that it is accessible to everyone, but no one can change the cadastral data. Despite the fact that there is a guarantee of information protection, there is a backup duplicate of the data bank in another place.

In Denmark, the cadastre is managed by the Cadastral Board, and there is an automated cadastral system in which information is stored on hard disks. Registration of rights is the responsibility of the Ministry of Justice, represented by the Judicial Department, Land Management and Cadastre-the National Service of Geodesy and Cadastre, which is accountable to the Ministry of Housing, and the Special Planning Department of the Ministry of Natural Resources and Energy is responsible for the rational use of land and its protection. Land assessment is carried out by the Ministry of Taxes and Duties (2001) Only certified surveyors united in a National Association have the exclusive right to carry out land management works in Denmark. In the Russian Federation, the Federal Service for State Registration, Cadastre and Cartography (Rosreestr) is a federal executive body that performs functions for state registration of rights to real estate and transactions with it, for conducting state cadastral registration of real estate, land management, state land monitoring, navigation support of the transport complex, as well as functions for state cadastral assessment, federal state supervision in the field of geodesy and cartography, state land supervision, supervision of the activities of self-regulating organizations of appraisers, control of the activities of self-regulating organizations of arbitration managers. The main feature of the land cadastre model used in the UK is the division of functions between services that conduct surveys and perform cartographic work, and services that register real rights to land and keep records of specialized 
information on land. Thus, the Royal State Land Registration of Land rights, including property rights, mortgages, encumbrances and easements, the State Topographic Service (GTS) - Ordnance Survey forms topographic and geodetic and cartographic support, registers information about land plots and the Ministry of Agriculture takes into account data on land use and classification of agricultural land, the Department for Environmental Protection, Transport and Regions takes into account data on land use on land of other categories. The Royal State Land Registry (KGZRP)-NM Land Registry is a public administration Department of the Lord Chancellor of the Ministry of Justice and consists of 24 regional offices of the KGZRP (district offices) in England and Wales, which serve a specific geographical area, which includes several municipalities. Each district office is headed by a district registrar, who must be a lawyer under the terms of the Land Registration Act. It has broad judicial rights to legally confer title to land property and to resolve disputes. Based on the analysis of the current legislation, which revealed the imperfections of cadastral activity, taking into account the best foreign experience in the field of cadastral activity of the above, in order to further improve cadastral activity in the republic, to streamline public administration in the field of state cadastre, we offer:

1. Create a single cadastral body - the Cadastral Service of the Republic of Uzbekistan under the Ministry of Justice of the Republic of Uzbekistan, the main and only function of which will be the maintenance of state cadastres with the condition of attracting public-private partnership. The creation of this body will contribute to: first, the release of public administration bodies from the uncharacteristic task of maintaining state cadastres; second, the establishment of a unified approach and a unified methodology for the formation of cadastral information; third, it will avoid the "fragmentation" of existing natural resources inventories and the duplication of powers of the competent authorities; fourth, it will increase the reliability of cadastral information, thereby ensuring the authority of the state cadastre; fifth, the involvement of public-private partnerships in the cadastral sphere will solve the issue of financing cadastral activities. In conclusion, I would like to note that cadastral activities in the field of environmental protection, although not a new activity for us, but in the context of sustainable economic development requires a radical revision of the basics of its management. The success of the ongoing socio-economic reforms and, in general, the fate of the state depends on the availability of reliable information about natural resources.

\section{REFERENCES}

1. Sobirovna T. R. Issues of further improvement of water cadastre legislation of Uzbekistan /IACADEMICIA: An International Multidisciplinary Research Journal. - 2021. - T. 11. - №. 4. C. 1241-1253.

2. Тошбоева, Р. С. (2019). ПРАКТИЧЕСКИЕ АСПЕКТЫ ЭКОЛОГО-ПРАВОВОГО ВОСПИТАНИЯ ОБЩЕОБРАЗОВАТЕЛЬНЫХ ШКОЛАХ. In Теоретические аспекты юриспруденции и вопросы правоприменения (рр. 6669).

3. Тошбоева, Р. С. (2019). ПРАКТИЧЕСКИЕ АСПЕКТЫ ЭКОЛОГО-ПРАВОВОГО ВОСПИТАНИЯ B ОБЩЕОБРАЗОВАТЕЛЬНЫХ ШКОЛАХ. In Теоретические аспекты юриспруденции и вопросы правоприменения (рр. 6669).

4. Асрор Ахмедович Мустафакулов, Аббос Набиджонович Джуманов, \& Фазлидаин Арзикулов (2021). АЛЬТЕРНАТИВНЫЕ ИСТОЧНИКИ ЭНЕРГИИ. Academic research in educational sciences, 2 (5), 1227-1232. doi: 10.24411/2181-1385-2021-01019 
5. Akhmedovich, M. A., \& Fazliddin, A. (2020). Current State Of Wind Power Industry. The American Journal of Engineering and Technology, 2(09), 32-36.

6. Мустафакулов, А. А., Арзикулов, Ф. Ф., \& Джуманов, А. (2020). Использование Альтернативных Источников Энергии В Горных Районах Джизакской Области Узбекистана. Интернаука: электрон. научн. журн, (41 (170)).

7. Нариманов, Б. А. (2020). ВОЗОБНОВЛЯЕМЫЕ ИСТОЧНИКИ ЭНЕРГИИ, ВОПРОСЫ УСТОЙЧИВОСТИ И СМЯГЧЕНИЯ ПОСЛЕДСТВИЙ ИЗМЕНЕНИЯ КЛИМАТА. Universum: технические науки, (10-3), 66-70.

8. Послание Президента Республики Узбекистан Шавката Мирзиёева Олий Мажлису, Народное слово, - 2018., - 29 декабря, - № 234 (1234). 3. https://prirodnie resursi h//studfiles.net/preview/3557152/.

9. Schlomer T. Berufliches Handeln und Kompetenzen fur nachhaltiges Wirtschaften:ein Referenzmodellauf der Grundlage theoretischer und empirischer Explorationen,(Schriften zur Berufs-und Wirtschaftspadagogik,Bd.6), Mering Hampp - 2009., - № 16, - S 407.

10. Земельный Кодекс Республики Узбекистан, Адолат, - Т., - 2016. 6. Закон Республики Узбекистан «О Государственных кадастрах» от 15 декабря - 2000. http://lex.uz/docs/19480.

11. Закон Республики Узбекистан «О государственном земельном кадастре» $\begin{array}{llll}\text { от } 28 & 28 & \text { августа } & 1998\end{array}$ http://lex.uz/docs/7086.

12. «Положение о порядке создания и ведения Единой системы государственных кадастров», утвержденное Кабинетом Министров Республики Узбекистан от 16 февраля 2005. - № 66. http://lex.uz/docs/916217.

13. «Положение о порядке ведения государственного земельного кадастра» утвержденное Постановлением Кабинета Министров
Республики Узбекистан от 31 декабря 1998. № 543. 